\title{
Technical Tours as Special Interest Tourism in the Urban Context: A case study of Kuala Lumpur
}

\author{
Khalilah Zakariya, Roziha Che Haron, \\ Zeenat Begam Yusof, Illyani Ibrahim
}

\author{
Kulliyyah of Architecture and Environmental Design \\ International Islamic University Malaysia, Gombak, Malaysia \\ khalilah@iium.edu.my, roziharon@iium.edu.my, zeensoni@iium.edu.my, illyani_i@iium.edu.my \\ Tel: +60364216293
}

\begin{abstract}
Studies on Special Interest Tourism (SIT) have gained an increasing attention within the last decade. This article examined the potentials of attractions in Kuala Lumpur that can attract built environment professionals as a niche group of tourists. Based on analysing secondary data sourced from technical tours, tour packages and attractions promoted by different agencies, this study mapped, tabulated and examined existing buildings and sites with their unique characteristics. 58 buildings and sites showed potentials as tourism attractions for built environment professionals through technical tours. A customised experience can be high-yield as they are tailor-made to special interest tourists.
\end{abstract}

Keywords: Built environment; special interest tourism; technical tours; urban tourism.

eISSN: 2514-751X@ 2020 The Authors. Published for AMER ABRA cE-Bs by e-International Publishing House, Ltd., UK. This is an open access article under the CC BY-NC-ND license (http://creativecommons.org/licenses/by-ncnd/4.0). Peer-review under responsibility of AMER (Association of Malaysian Environment-Behaviour Researchers), ABRA (Association of Behavioural Researchers on Asians) and CE-Bs (Centre for Environment-Behaviour Studies), Faculty of Architecture, Planning \& Surveying, Universiti Teknologi MARA, Malaysia.

DOI: https://doi.org/10.21834/ajebs.v5i16.370 


\subsection{Introduction}

Urban tourism attracts tourists by promoting places for sightseeing, shopping, business and leisure activities, which comprise of 'a broad and heterogeneous range of cultural, architectural, technological, social and natural experiences and products' (UNWTO, n.d.). Tourism contributes to the growth of cities by boosting the business ecosystem through the services and products provided. While urban tourism caters for various segments of tourists such as the mass tourists, business tourists, cultural tourists and free independent travellers, an emerging segment of tourists has grown within the last ten years. The emerging tourist segment is the Special Interest Tourist (SIT). SIT seeks for unique or tailor-made tourism activities according to their interests that may be related to their professions, hobby or particular experiences that are not very common to the masses (Brotherton \& Himmetoglu, 1997; Soleimani et al., 2019; Trauer, 2006). Although the composition of SIT in the broader tourism population may be small, the groups of tourists in this segment have potentials to generate a high yield.

Among the business tourists, or those who attend meetings, incentives, conferences and exhibitions (MICE), there is a segment of SIT comprising of built environment professionals and design enthusiasts, such as landscape architects, architects, quantity surveyors, planners, engineers and others. As part of continuous professional development, they often participate in technical tours during events and conferences. Though it is common for professionals to engage in technical tourism experiences, some cities have begun to open up the experience to the public. In 2018, 42 cities around the world participated in the Open House Worldwide event where sites and buildings opened their doors for the public to visit (Open House, 2018). The concept of Open House started in London in 1992, to make sites and buildings accessible to people as an opportunity to learn and experience the city. According to Open House London, 'each year, over a quarter of million people take part in the Open House weekend, visiting over 800 buildings, walks, talks and tours across London' (Open City, 2017). The Open House activities were able to generate income for the cities. For example, over the ten years of the Open House Melbourne events from 2008 until 2018, the city estimated an income of AUD20 million (approximately MYR55 million) (Open House Melbourne, 2018).

Malaysia also practised the similar open house concept where professional bodies conduct technical tours to sites, buildings, structures, parks, factories and at times the city at large. However, at the moment, tourism agencies do not yet promote the open house concept or technical tours as part of the urban tourism activities, although they are extensions of MICE tourism. The Malaysian Convention and Exhibition Bureau (Malaysia Convention and Exhibition Bureau, 2017) reported that business events held in 2017 were able to generate an estimated RM954 million for the country's economy. This astounding figure shows significant potentials of technical tours in Malaysian cities as a form of SIT targeting at built environment professionals and design enthusiasts. As the capital city of Malaysia, Kuala Lumpur is home to an array of sites and buildings that can attract SIT through technical tours. Like the open house concept, technical tours have potentials to reveal the vibrant characters of Kuala Lumpur, reinforcing appreciation for culture, built environment, lifestyle and 
technology, while at the same time, strengthening the sense of place, sense of harmony and safety in the city (Cave \& Jolliffe, 2015: H. N. Ismail, 2008; Lerario \& Turi, 2018).

The purpose of this study was to explore the potentials of technical tours for Special Interest Tourism (SIT) in Kuala Lumpur. The first objective of the study was to identify buildings, outdoor spaces and structures included in technical tours and promoted for customised tours. The second objective was to examine their locations, types and uniqueness in attracting built environment professionals and design enthusiasts.

\subsection{Literature Review}

\subsection{Special Interest Tourism}

The term Special Interest Tourism, or SIT, is defined to be similar to alternative, sustainable, appropriate, or new tourism, which sets it apart as other types of tourism that are not generic (Rittichainuwat, 2018; Trauer, 2006). Among the different types of SIT are design enthusiasts, who are those that are passionate about design and elements of design as previously demonstrated in the open house concept. Built environment professionals are also a type of SIT as they often engage in activities that are in line with the creative and technical fields. Technical tours for built environment professionals and design enthusiasts are common throughout the world. Switzerland Tourism promotes 43 technical tours throughout the country to offer tourists unique behind-the-scene visits, such as to power stations, tunnels, buildings and factories (Switzerland Tourism, 2020). Similarly, Open House Melbourne opened doors to 219 places in 2018 to allow people to visit places of various categories, such as commercial, cultural, education, government, industrial, landscape, place of worship, residential, sports facility, transport and workplace. The visits intend to foster a better understanding of places in the city. Ramli and Ujang (2020) suggested that 'creative placemaking' can encourage the growth of the arts, culture and creativity to transform cities. In Malaysia, professional bodies in the built environment field have organised technical tours to newly designed buildings and parks, conserved historical buildings and structures under construction.

MICE tourism, which are meetings, incentives, conferences and exhibitions, pull a different typology of tourists, such as businessmen, academicians and researchers, government agencies, professional bodies, students and specific niche groups of people (Hinch, 1996). MICE activities take place at hotels, convention halls and indoor venues. Professional bodies often conduct MICE events as part of their continuous professional development, such as through conferences and seminars on the built environment, natural environment, laws, medicine, engineering and others. In Japan, technical visits are part of industrial tourism where tourists go on factory visits and technical tours to observe various technology, systems and facilities (Ito et al., 2017). Customised tours catered to special interest tourists allowed the tourists to have a more specific technical information that is relevant to their field of interest. Most conferences and congresses 
nowadays offer technical visits as an additional package to the participants as a way to allow the participants to enjoy the place of visit while gaining new knowledge.

In other words, SIT is the opposite of mass tourism. SIT caters for a niche market segment, which may be of a small percentage but has potentials to be high yield. According to the Department of Statistics Malaysia (2018), the purposes of visit for domestic tourism in Malaysia are predominantly for visiting relatives and friends (40.6\%), followed by shopping $(34.7 \%)$, holiday, leisure or relaxation (10.4\%), entertainment, attending special event or sport $(5.2 \%)$, and seeking medical treatment or wellness (4.6\%). Malaysia has targeted to become a leading business tourism destination by 2020 , and this ambition provides a significant opportunity to promote certain urban attractions among design enthusiasts.

\subsection{Architecture and landscape as attractions}

Tourism has a strong relationship with the built environment. Tourists visit places to gain experience and knowledge in terms of history and culture, which are always represented by buildings and the landscape (Medina \& Brian, 2004). In 2002, a conference held in Columbia University defined architectural tourism as Architourism, which means "architecture as a destination for tourism" (Shaw, 2008). Indeed, architecture, parks, natural landscape and heritage sites as destinations for tourism is not a new phenomenon. It existed since the times of Great Pyramids and Seven Wonders of the ancient world. However, in the recent decades architecture becomes a notable subject of tourism when famous architect Frank Gehry built the Guggenheim Bilbao Museum in 1997, which is considered as 'signature architecture'. This building has attracted millions of tourists around the world. Since then, many countries create famous signature buildings to attract tourists. For example, Burj Khalifa in Dubai, KLCC in Malaysia, Guangzhou Opera House in China by Zaha Hadid and many more. Parks and public spaces also attract people to visit the city. Landscape can draw people into outdoor spaces because of the natural setting. According to Ganser (2017), when the High Line, which is an elevated linear park in New York, opened to the public in 2009, it received 1.3 million visitors. In 2015, the number of visitors reached 7.6 million. Architectural tour, a 'nonacademic' or design tours, are created by many countries for tourist to experience the architecture, nature, culture and history (Craggs et al., 2013). However, Malaysia currently lacks this kind of tourism service. Said $(2018)$ suggested that cities with heritage assets should diversify tourism products. Therefore, Open House Malaysia can be a stepping stone for Malaysia Architourism and design tourism.

A city generates economic activities by providing varieties of job and business opportunities. Cities provide the efficient use of space that forms a liveable city for the urban inhabitants. The daily lifestyle of people filled with busy work activities and routines make a person long for leisure activities to relax and seek peace of mind (Cave \& Jolliffe, 2015). Urban tourism is one of the activities where people can detour temporarily from their daily routines by gaining a new experience of culture, heritage and environment of a new area and immersing in the unique cultures of a place (Cave \& Jolliffe, 2015; Lerario \& Turi, 2018). 


\subsection{Heritage assets}

Cultural heritage tourism offers a unique experience for tourists to appreciate cultural environments such as sites, landscapes and structures, which falls under tangible heritage in the form of buildings or artefacts or sites. Some of the examples are buildings and areas of historical and cultural significance, such as Merdeka (Independence) Square, the National Mosque, the Sultan Abdul Samad building and many others. Heritage tourism can help to protect and safeguard the history of the sites from damage, demolition or removed from its context. These losses will significantly affect the traditional knowledge and its 'scientific and technical' information as a genuine source. In another note, it will help to provide character, as well as aesthetic and educational interest to what has come to be called cultural heritage. Further, Malaysia is a multi-cultural society, composed of people of very diverse origins. From the multiracial and multi-religious population of Malaysia, tourists can find a variety of places of worship, such as mosques for Muslims and temples for Buddhists and Hindus. This uniqueness itself appears as one of the best attraction factors in the Malaysian tourism sector. The Heritage of Malaysia Trust is one of the non-profit organisations that promotes the preservation of buildings with architectural and historical significance in the country. The main objectives of its role are to protect the National Heritage for the benefit, education and enjoyment of the people of Malaysia and overseas visitors.

The city's heritage assets are usually preserved and showcased in places such as museums, galleries, sites, parks, through its townscape elements and the conservation of urban villages as a way of sustaining the city's sense of place. Locals and tourists can learn about the history and growth of the city through the planning, design and construction methods. Conservation initiatives of the heritage help to protect and preserve the urban structures and elements from being demolished. These structures and elements become valuable landmarks, especially for the younger generations to study and understand the city's culture and heritage (Bădiţă, 1994; Chen \& Thapa, 2017). It can be a beneficial experience and learning not only for the tourists but also to the local communities.

\subsection{The city experience}

The nature of city tourism is changing due to the availability of mobile access to information. The concept of smart cities can manage tourist flows in the future as it also offers new opportunities to the government and city planner for a reflection of physical spaces (Bock, 2015). Using such Big Data, some city and tourism authorities can understand the gap between the tourists' and residents, thus able to develop solutions. An awareness of residents toward tourism can benefit the locals' attitude positively. Therefore, locals must take an active part in the planning process rather than be informed (Marzuki \& Hay, 2013). Lerario and Turi (2018) listed the threats derived by the use of outdoor spaces, such as undermining of visual perception of the site and an increase in air pollution. Liu (2003) advised a "safe minimum standard" approach by applying the concept of "carrying capacity" as a critical concept for tourism that requires adequate planning and operational control. It is fundamental to extend the indicators on the built environment, especially in cultural tourism, in which it is one of the driving forces of tourist flows that affect the built environment (Lerario \& Turi, 2018). 
The urban area is an area that has a high concentration of population that serves to provide economic activities for income generation, better lifestyle and education to the urban communities. In Malaysia, tourism is the most significant contributor to Malaysia' GDP leading industry after manufacturing and commodities. In 2018, the tourism sector contributed an average of $5.9 \%$ to the total GDP (Hirschmann, 2020). Cities offer a variety of cultural, artistic and recreational experiences to the urban dwellers and visitors (Blank \& Petkovich, 1987; Hinch, 1996; Negrusa \& Yolal, 2012). There are distinct and recognisable characters that compose the fabric of the city shaped by the natural environment, built environment, heritage, lifestyle and ancillary elements found in a particular setting. All these elements contribute to the generation of urban tourism. The tourism markets range from cultural (including festival or art), historical and even congress, sporting, gastronomic, night-life, shopping and many more. Besides, for various reasons, cultural heritage tourism is essential and contributing to a positive economic, and social impact such as it creates and reinforces identity.

Further, urban tourism helps to conserve cultural heritage, and subsequently, it promotes culture and helps to renew tourism (Ismail et al., 2014). The amalgamation of these rich characters attract Special Interest Tourists (SIT) to visit specific sites and buildings to experience more than just the story of the place but also to know how they are built, how they function and what people can learn from it. SIT seeks experiences that offer varying qualities, ambience and complexities with specific interest-based motivation for their travels (Brotherton \& Himmetoglu, 1997; Trauer, 2006).

\subsection{Methodology}

\subsection{Study area}

This research selected Kuala Lumpur as a case study because it is a significant hub for urban tourism in Malaysia. The general types of tourism products in Kuala Lumpur are cultural heritage attractions, urban visitor resources, and recreational and health resources (refer Fig. 1) (City Hall Kuala Lumpur, 2020). According to EdgeProp.my (2019), Kuala Lumpur is ranked 10th for quality of life in Asia, based on the Mercer Quality of Living City Ranking Survey 2019.

\subsection{Data collection and analysis}

The study collected data from online secondary sources, by tabulating a list of technical tours from four professional bodies and four other agencies comprised of a government body and tour organisers. The researchers then mapped the locations of the buildings, outdoor spaces and structures, and thematically analysed the distinctive characteristics of the attractions according to their design and technical features. The thematic analysis showed characteristics of the attractions that are unique to attract SIT, which could become critical findings to propose design tours in Kuala Lumpur. 


\subsection{Limitation of the study}

The researchers acknowledge a limitation to the study. The data were obtained from secondary sources based on the lists provided by the respective professional bodies and tour organisers that were easily accessible online. While the attractions on the list may or may have not all been visited by the built environment professional, they indicate that the attractions have been selected to be promoted for such tours due to their relevance to the built environment and design professions.

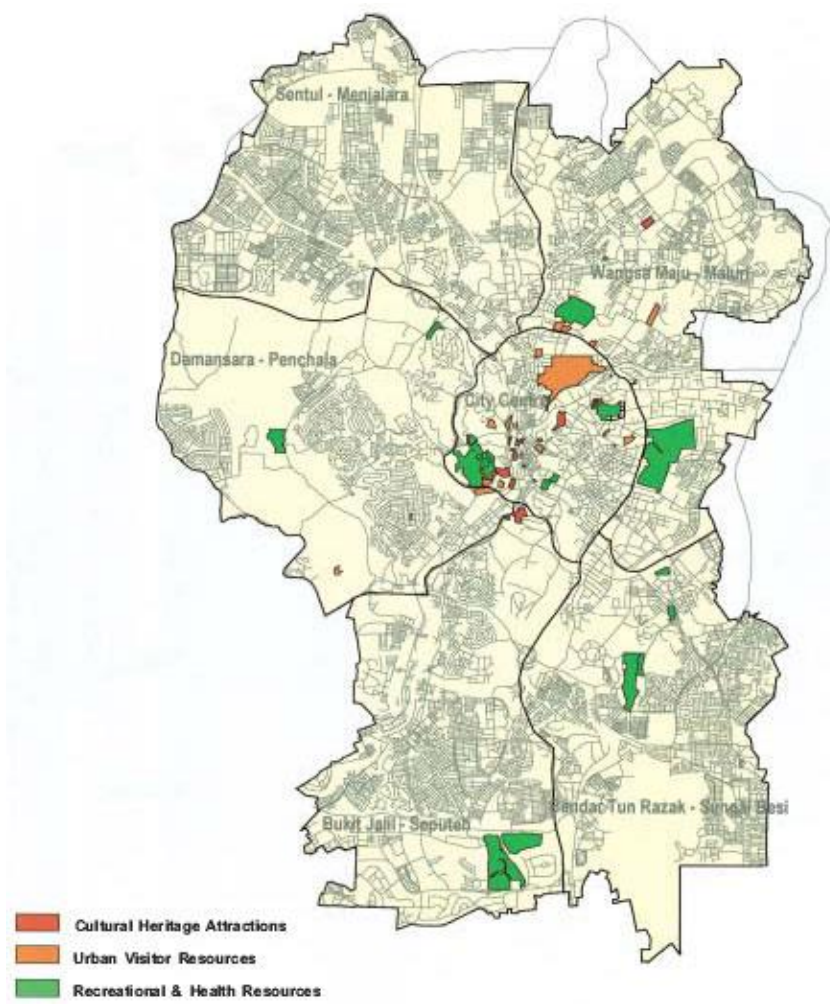

Fig. 1: Distribution of tourism products in Kuala Lumpur (Source: City Hall Kuala Lumpur, 2000)

\subsection{Results}

\subsection{Special Interest Tourism attractions in Kuala Lumpur}

From the data tabulated, the study found that professional bodies and tour organisers promote a total of 58 attractions in Kuala Lumpur for design enthusiasts and built environment professionals 
(refer Table 1). The attractions comprise 44 buildings, ten outdoor spaces (parks, streets, heritage zones), and four structures (tunnel, transit stations). The professional bodies conducted the visits during special programmes, such as SPARK: International Landscape Architecture Dialogue, SINGGAHKL 2019, conferences and as part of annual activities. On the other hand, the tour organisers promote the buildings and sites to attract tourists who are interested in architecture and design.

Table1: List of sites and buildings in Kuala Lumpur visited by built environment professionals and design enthusiasts

\begin{tabular}{|c|c|c|c|}
\hline $\begin{array}{c}\text { Professional } \\
\text { Bodv/Tour Orqaniser }\end{array}$ & $\begin{array}{c}\text { Nature of } \\
\text { Fent/Prome }\end{array}$ & \multicolumn{2}{|c|}{ Site \& Buildings } \\
\hline $\begin{array}{l}\text { Institute of Landscape } \\
\text { Architects Malaysia (ILAM) } \\
\text { Source: Institute of } \\
\text { Landscape Architects } \\
\text { Malaysia (2019) }\end{array}$ & Technical Tour & $\begin{array}{l}\text { - Sekeping Tenggiri } \\
\text { - APW Bangsar } \\
\text { - PAM Centre } \\
\text { - KL Historical Area } \\
\text { - Taman Tugu }\end{array}$ & $\begin{array}{l}\text { - Lorong Bandar } 13 \\
\text { - River of Life } \\
\text { - Bukit Bintang Street } \\
\text { Art } \\
\text { - GMBB KL }\end{array}$ \\
\hline $\begin{array}{l}\text { Pertubuhan Arkitek Malaysia } \\
\text { (PAM) } \\
\text { Sources: } \\
\text { Pertubuhan Akitek Malaysia } \\
(2019 ; 2020)\end{array}$ & Technical Tour & $\begin{array}{l}\text { - PAM Centre } \\
\text { - Rumah Tangsi } \\
\text { - Pusat Kreatif Kanak- } \\
\text { Kanak Tuanku Bainun } \\
\text { - Asian Institute of } \\
\text { Chartered Bankers } \\
\text { - The International } \\
\text { School of Kuala Lumpur }\end{array}$ & $\begin{array}{l}\text { - Hotel Stripes KL } \\
\text { - Pusat Genius Kurnia } \\
\text { - Chocha Foodstore } \\
\text { - Chan She Shu Yuen } \\
\text { Clan Ancestral Hall, } \\
\text { - Lantern Hotel, } \\
\text { - Mingle Hostel Café } \\
\text { - Jao Tim }\end{array}$ \\
\hline $\begin{array}{l}\text { Royal Institute of Surveyors } \\
\text { Malaysia (RISM) } \\
\text { Source: Royal Institution of } \\
\text { Surveyors Malaysia (2017) }\end{array}$ & Technical Tour & Equatorial Plaza & \\
\hline $\begin{array}{l}\text { Institute of Engineers } \\
\text { Malaysia (IEM) } \\
\text { Source: The Institution of } \\
\text { Engineers Malaysia (2019) }\end{array}$ & Technical Tour & $\begin{array}{l}\text { - SMART Tunnel } \\
\text { - MRT } 2 \text { Sentul West }\end{array}$ & $\begin{array}{l}\text { - IKEA, MyTown } \\
\text { - Bukit Bintang MRT } \\
\text { Station }\end{array}$ \\
\hline $\begin{array}{l}\text { Tourism Malaysia } \\
\text { Source: Malaysia Tourism } \\
\text { Promotion Board (2018) }\end{array}$ & Recommended Places & $\begin{array}{l}\text { - Countdown Clock } \\
\text { - Kuala Lumpur } \\
\text { - National Museum } \\
\text { - Petronas Twin Towers } \\
\text { - Kuala Lumpur Tower } \\
\text { - Islamic Arts Museum } \\
\text { - Masjid Jamek } \\
\text { - National Monument } \\
\text { - Bank Negara Museum } \\
\text { and Art Gallery Sasana } \\
\text { Kijang }\end{array}$ & $\begin{array}{l}\text { - Little India Brickfields } \\
\text { - Petaling Street } \\
\text { - Kampung Bharu } \\
\text { - Istana Budaya } \\
\text { - National Mosque } \\
\text { - National Textile } \\
\text { Museum } \\
\text { - Sultan Abdul Samad } \\
\text { Building }\end{array}$ \\
\hline $\begin{array}{l}\text { South East Asia Architecture } \\
\text { Guides } \\
\text { Source: Welch (2020) }\end{array}$ & Tour (Personal/Group) & $\begin{array}{l}\text { - Petronas Twin Towers } \\
\text { - Dayabumi Complex } \\
\text { - Kuala Lumpur Tower } \\
\text { - Maybank Tower } \\
\text { - The Troika }\end{array}$ & $\begin{array}{l}\text { - Masjid Jamek } \\
\text { - Masjid Negara } \\
\text { - Sri Maha } \\
\text { Mariamman Temple }\end{array}$ \\
\hline $\begin{array}{l}\text { GPS My City } \\
\text { Source: Valery (2020) }\end{array}$ & Tour (Self-Guided) & $\begin{array}{l}\text { - Royal Selangor Club } \\
\text { - Coliseum Theatre }\end{array}$ & $\begin{array}{l}\text { - National Craft } \\
\text { Complex }\end{array}$ \\
\hline
\end{tabular}




\begin{tabular}{|c|c|c|c|}
\hline & & $\begin{array}{l}\text { - Sultan Abdul Samad } \\
\text { Building } \\
\text { - Dayabumi Complex } \\
\text { - Central Market } \\
\text { - Maybank Tower } \\
\text { - St. John's Institution } \\
\text { - Suria } \\
\text { KLCC, Petrosains, } \\
\text { Galeri Petronas }\end{array}$ & $\begin{array}{l}\text { - Bukit Bintang } \\
\text { - Petaling Street } \\
\text { (Chinatown) } \\
\text { - Royal Malaysian } \\
\text { Police Museum } \\
\text { - Islamic Arts Museum } \\
\text { Malaysia } \\
\text { - Textile Museum } \\
\text { - Muzium Telekom }\end{array}$ \\
\hline Others & $\begin{array}{l}\text { Researchers' } \\
\text { additional list }\end{array}$ & \multicolumn{2}{|c|}{$\begin{array}{l}\text { - Tun Razak Exchange } \\
\text { - Warisan Merdeka (PNB 118) } \\
\text { - Saloma Link Bridge } \\
\text { - National Visual Arts Gallery } \\
\text { - National Library } \\
\text { - National Craft Complex } \\
\text { - Menara Muamalat (formerly Menara Bumiputera) } \\
\text { - Other newly constructed buildings and parks }\end{array}$} \\
\hline
\end{tabular}

\subsection{Distribution of attractions}

Tourists can find most of the attractions in the central business district of Kuala Lumpur (refer Fig. 2). As shown in the map, the majority of the buildings are concentrated within the vicinity of each other. Their locations are within the commercial zone of Kuala Lumpur. The clustering of buildings denotes that there are many attractions near each other, which means that they can easily be integrated or packaged in a tour or trail. The outdoor spaces, such as the park, riverfront and street, are also nestled among the buildings. Meanwhile, structures are distributed within the concentrated area as well as in the outer areas. Since the structures are linear, such as transit lines and tunnels, it is understandable that their points of interest may stretch beyond the city.

\subsection{Typology of attractions}

According to the data presented above, buildings made up the primary types of attractions for SIT. From the thematic analysis of the design and technical features, 19 buildings (43\%) featured contemporary design concepts, while 25 buildings $(57 \%)$ incorporated traditional design features and elements. For example, Figure 3 shows the minaret design of Masjid Negara (National Mosque) resembles the folded umbrella, which is inspired by the 'payung kertas' concept with 16 points (Mah, 2015). The National Craft Complex flaunts its Malay Terengganu architectural design with a Malaysian-themed landscape (Malaysian Handicraft Development Corporation, 2019), while the Royal Selangor Club in Figure 4 displays its Tudor revival architecture (Royal Selangor Club, 2020). Alongside the traditionally inspired architecture are the modern buildings, such as the recently completed Hotel Stripes in Figure 5 that juxtaposes 19th Century architecture and setting with a modern high-rise hotel (Liew, 2017). The outdoor spaces also range from natural and built, as well as heritage and contemporary. From the ten outdoor spaces, nine are townscape elements such as an urban village, streets and riverfront, while one is an urban park. For example, Taman Tugu, as shown in Figure 6, showcases its 66-acre urban forest park that has more than 200 species of trees (Taman Tugu Project, 2020). Meanwhile as illustrated in Figure 7, Bukit Bintang streets display vibrant street art to encourage people to experience the city on foot from the MRT stations, which is part of the urban renewal project by City Hall Kuala Lumpur (Prasarana Malaysia Berhad, 2019). Structures also become attractions to SIT. From the four structures included in the 
technical tours, three are completed projects, and one is the MRT station under construction. Construction sites offer behind-the-scene experiences, while completed structures such as the SMART Tunnel in Figure 8 allows visitors to learn the construction design, methods and technicalities of flood mitigation system (IEM Training Centre Sdn. Bhd., 2020).

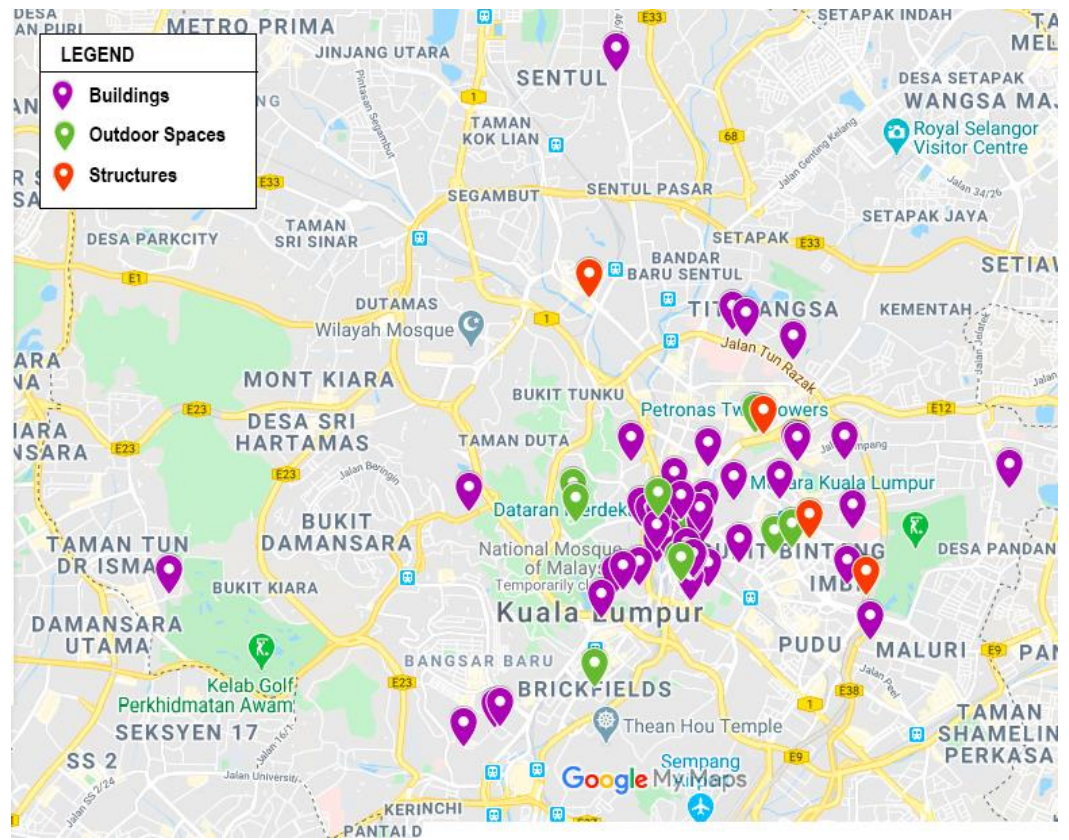

Fig. 2: Locations of sites and buildings in Kuala Lumpur visited by built environment professionals and design enthusiasts

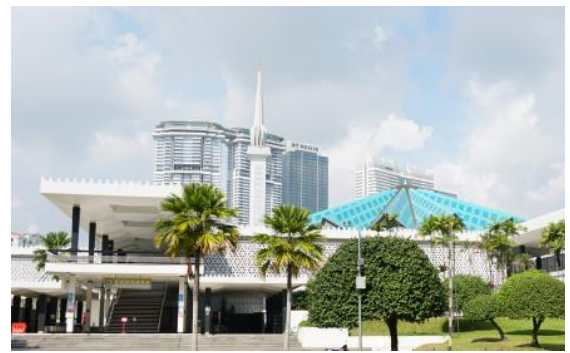

Fig. 3: Masjid Negara (National Mosque)

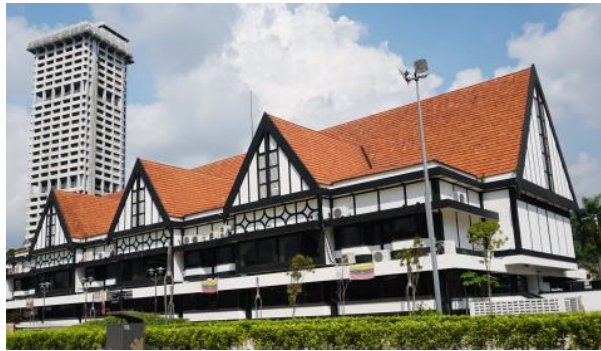

Fig. 4: Royal Selangor Club 


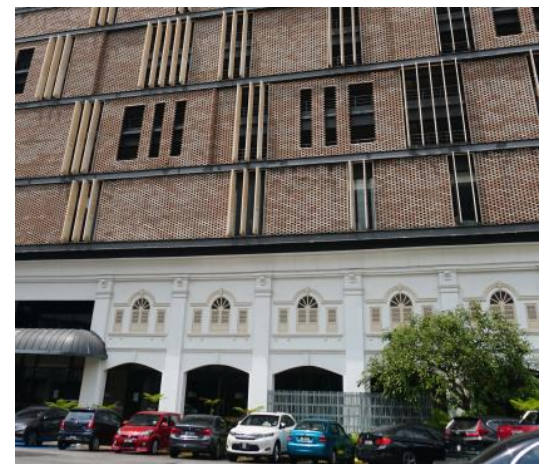

Fig. 5: Hotel Stripes

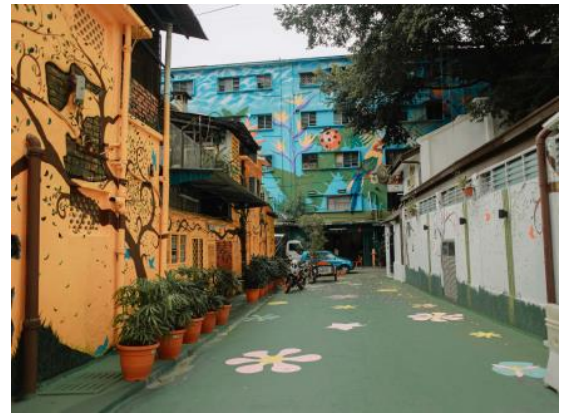

Fig. 7: Bukit Bintang Street Art

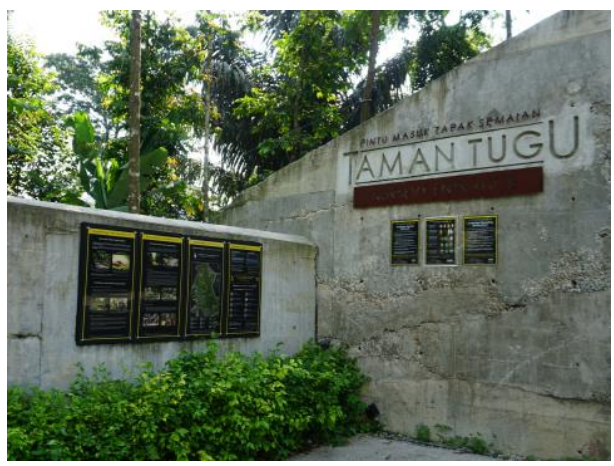

Fig. 6: Taman Tugu

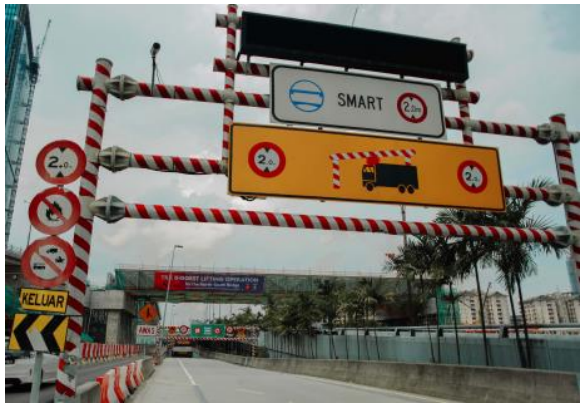

Fig. 8: SMART Tunnel

\subsection{Discussion}

\subsection{Characteristics of attractions}

Kuala Lumpur is the capital city of Malaysia. The Kuala Lumpur Structure Plan 2020 was established in 2012 to achieve Kuala Lumpur as an international tourism destination (Anuar et al., 2013). City Hall Kuala Lumpur (DBKL) has achieved its objective by providing integrated transportation services, shopping facilities, walkways, conference venues, entertainment facilities, refurbishment of Klang River (River of Life), upgrading of open space and parks, conservation of heritage buildings and construction of the signature buildings, such as Warisan Merdeka PNB 118, The Troika, Tun Razak Exchange and many more. Architectural attractions in Kuala Lumpur encompass heritage buildings and ultra-modern buildings. The heritage trails recommended by various bodies and tour organisers are located in the historic heart of the city, as presented in the findings. These buildings create distinctive "experiencescapes" that enhance the experiential aspect of tourism and hospitality products (Tresidder \& Deakin, 2019). Meanwhile, modern buildings located near the city centre, such as hotels, shopping complexes and service apartments, complement these attractions. The 
heritage and modern buildings in Kuala Lumpur, urban parks, streets and riverfronts are potentials for design tours for SIT.

Built environment professionals and design enthusiasts are similar to other special interest tourists such as sports, music and food enthusiasts, in the sense that they search for a particular experience to satisfy their interest. All cities have a multitude of attractions that can attract these SITs, where they can see, experience and learn about how those places and elements are built and work. The behind-the-scene experience can shed a different light of appreciation to the city. It can make an old attraction seem new from diverse perspectives. On a different note, to appreciate, preserve and maintain heritage values, urban tourism must also be concerned in understanding the impact of tourism on local communities and areas, achieving economic and social benefits, providing financial support for protection, as well as marketing and promotion.

\subsection{Economic activities for the city}

Tourism is a robust platform for economic development that creates jobs, creates new business opportunities and enhances explicitly local economies. The tourism industry can also help protect the natural and cultural resources of the country and improves the quality of life for residents using a proper way. As demonstrated by Open House London, Open House Melbourne and Switzerland Tourism, design tours for SIT have significant potentials to generate income for the city. Adequate and enforceable protection measures need to be taken by the authority to create a thriving and sustainable tourism industry. The buildings, monuments and significant sites need to remain and regularly preserved accordingly because of their value as tourist attractions. The economic factor is the dominant element taken into consideration in the planning of the tourism industry, due to its ability to earn foreign exchange and promote trade. Income generation is indeed an irresistible incentive for any country, especially those suffering from economic difficulties and capital scarcity. Tourism is also a means of economic diversification. Furthermore, tourism is also known for contributing to employment, including creating skilled, semi-skilled, or unskilled jobs for the local context. Job creation is a very significant factor, especially for countries with high rates of unemployment. The tourism industry helps to encourage people, especially the youth, to work and venture to a much cleaner working environment such as hotels, restaurants and theme parks. Nevertheless, the rapid development of the tourism industry also helps to increase land values in the destination areas, and this, in turn, creates an active environment for a land investment, which provides opportunities to local people to obtain more profit for their land.

\subsection{Promoting design tours in the city}

The findings revealed that the distributions of the attractions are concentrated in the central area of Kuala Lumpur. The SIT has progressed from the needs of the tourism industry to grow the destination experience, that not only to pursue leisure and recreational tourism. Digital marketing can generate a web-based information system in the tour and travel for SIT to facilitate the process of booking package tours. Providers of attractions should conduct market research to meet the needs of tourists, particularly the segments of SIT. Tourism 
market researchers can look specifically on the motivations and interests of tourists, travel choices and income levels by SIT locations and attractions. Finally, we need to understand the variations of SIT, which also includes adventure tourism, dark tourism and diverse kinds of cultural and heritage tourism.

The built environment is an essential urban component of the city, where the settings of the city landscape and the architectural styles, materials and histories of the buildings compose the destination image. In some cities, there are individual buildings, sites and urban landscapes that have been listed by UNESCO or the national agencies as important heritage sites, which needs to be conserved as part of the city's historical identity. Also uniquely in cities are the newer buildings and structures that complement or juxtapose the existing heritage buildings. When seen from the technical perspectives, the design features, materials and methods applied on the old and new buildings are valuable sources of knowledge that can also become exciting tourism products for special interest tourists, such as for design enthusiasts and built environment professionals. An example of a built structure that has become a tourist attraction is the Basilica Cistern in Istanbul, Turkey, which is an underground water reservoir. These behind the scene activities can offer an extraordinary experience to tourists while enriching their appreciation towards the city differently.

\subsection{Conclusion and Recommendations}

The study revealed that there is a high potential of design tours for SIT in Kuala Lumpur, with specific reference to built environment professionals and design enthusiasts. Though most of the sites and buildings identified already represent Kuala Lumpur's urban tourism attractions, however, they may not have been positioned from their technical aspects. The findings allude to the notion that attractions can be packaged in different ways when we value the characteristics from different perspectives, in this case, from their design and construction features. Design tours can link the attractions with unique themes. Such tours would not only promote the art, architectural and cultural values of the city. However, they will also generate spillover activities to the nearby attractions and services, such as cafes, public transportations, souvenir shops and others, and thus, generating income for the city. This study recommends for building owners, site managers, professional bodies and tour organisers to curate the attractions in the city for SIT, which can bring tourists to the less commonly accessible areas to offer them the behind-the-scene experiences. A customised experience that is different from activities engaged by mass tourists can be high-yield as they are tailor-made to specific interest groups. Further studies can examine the particular categories of attractions explored in this study, which are buildings, outdoor spaces and structures. This article concludes that design tours indeed have significant potentials to attract Special Interest Tourists, and can promote the city's vibrant design characters. 


\section{Acknowledgements}

This research was funded by the Research Initiative Grant Scheme (Publication) by International Islamic University Malaysia (P-RIGS18-016-0016).

\section{References}

Anuar, A. N. A., Ahmad, H., Jusoh, H., \& Hussain, M. Y. (2013). Policy and tourism development strategy towards tourist friendly destination in Kuala Lumpur. Asian Social Science, 9(2).

Bădiţă, A. (1994). Approaches to the analysis and evaluation of urban tourism system within urban destinations. Journal of Tourism Studies and Research in Tourism, 16, 58-66.

Blank, U., \& Petkovich, M. (1987). Research on urban tourism destinations. In J. R. B. Ritchie \& C. R. Goeldner (Eds.), Travel, Tourism and Hospitality Research (pp. 165-77). John Wiley \& Sons.

Bock, K. (2015). The changing nature of city tourism and its possible implications for the future of cities. European Journal of Futures Research, 3(20).

Brotherton, B., \& Himmetoglu, B. (1997). Beyond destinations-special interest tourism. Anatolia, 8(3), 11-30.

Cave, J., \& Jolliffe, L. (2015). Urban tourism. In P. Robinson (Ed.), Tourism: Key Concepts in Tourism (pp. 268-270). Routledge.

Chen, L., \& Thapa, B. (2017). Landscape optimisation in a highly urbanized tourism destination : An integrated approach in Nanjing, China. Sustainability, 9.

Craggs, R., Geoghegan, H., \& Neate, H. (2013). Architectural enthusiasm: visiting buildings with the Twentieth Century Society. Environment and Planning D: Society and Space, 31(5), 879-896.

Department of Statistics Malaysia. (2018). Press Release Domestic Tourism Survey 2018.

EdgeProp.my. (2019, March 13). KL and JB among top 20 Asian cities for quality of life: Survey. The Edge Markets. https://www.theedgemarkets.com/article/kl-and-jb-among-top-20-asian-cities-quality-life-survey

Ganser, A. (2017). High Line Magazine: B1G DA+A and Parks. High Line. https://www.thehighline.org/blog/2017/01/18/high-line-magazine-b1g-daa-and-parks/

Hinch, T. D. (1996). Urban tourism : Perspectives on sustainability. Journal of Sustainable Tourism, 4(2), 95-110.

Hirschmann, R. (2020). Travel and tourism in Malaysia - Statistics and facts.

www.Statista.Com. https://www.statista.com/topics/5741/travel-and-tourism-in-malaysia/

IEM Training Centre Sdn. Bhd. (2020). Site visit and technical tours - SMART Tunnel (Group 1). IEM Training Centre Sdn. Bhd.: Events. http://www.iemtc.com/events/details.aspx?id=2254\&AspxAutoDetectCookieSupport=1

Institute of Landscape Architects Malaysia, Institute of Landscape Architects Malaysia. (2019). SPARK: Landscape Architecture International Dialogue. Institute of Landscape Architects Malaysia (Official Website).

Ismail, H. N. (2008). Urban tourism concept in developing countries: Qualitative study to the case of Melaka city, Malaysia. Jurnal Alam Bina, 13(4). 
Ito, K., Kawamura, H., \& Kato, M. (2017). Technical visits and industrial tourism: A case study of AVEC Inc. Journal of Global Tourism Research, 2(1), 45-52.

Lerario, A., \& Turi, S. (2018). Sustainable urban tourism: Reflections on the need for building-related indicators. Sustainability, 10(6), 1-25.

Liew, J. (2017). Hotel Stripes Kuala Lumpur set to revive historical Jalan Kamunting. Tatler Malaysia.

Liu, Z. (2010). Sustainable Tourism Development: A Critique. Journal of Sustainable Tourism, 11(6), 459-475.

Mah, K. (2015, September 5). The man behind Masjid Negara's iconic "umbrella" dome. Malay Mail.

Malaysia Convention and Exhibition Bureau. (2017). Annual Report 2017.

Malaysia Tourism Promotion Board. (2018). Explore Malaysia: Kuala Lumpur. Official Website of Tourism Malaysia. https://www.malaysia.travel/en/my/places

Marzuki, A., \& Hay, I. (2013). Towards a public participation framework in tourism planning. Tourism Planning \& Development, 10(4), 494-512.

Medina, L., \& Brian, M. (2004). Architecture and Tourism Perception. Bloomsbury.

Negrusa, A., \& Yolal, M. (2012). Cultural tourism motivation - The case Of Romanian youths. Annals of Faculty of Economics, 1(1), 548-553.

Open City. (2017). About Open House. Open House London. https://openhouselondon.org.uk

Open House. (2018). 2018 Open House Worldwide season kicksoff with Open House Santiago. Open House Worldwide. https://www.openhouseworldwide.org

Open House Melbourne. (2018). Building Custodian's Guide. Open House Melbourne.

Pertubuhan Akitek Malaysia. (2020). Architectural Building Visit. KLAF2020: Kuala Lumpur Architecture Festival "Beyond." https://www.klaf.my/events/architectural-building-visit/

Pertubuhan Akitek Malaysia dan Pusat Binaan Sdn. Bhd. (2019). SINGGAHKL 2019. Pertubuhan Akitek Malaysia. http://www.pam.org.my/events/announcements/1413-singgah-kl-2019.html

Prasarana Malaysia Berhad. (2019). Art Street - MRT Bukit Bintang. MyRapid: Explore the City.

Rittichainuwat, B. N. (2018). Special Interest Tourism. Cambridge Scholars Publishing.

Royal Institution of Surveyors Malaysia. (2017). Technical Visit to Equatorial Plaza, Kuala Lumpur. RISM Official Website. https://rism.org.my/event/technical-visit-to-equatorial-plaza-kuala-lumpur-2/

Royal Selangor Club. (2020). Royal Selangor Club History. Royal Selangor Club. http://www.rsc.org.my

Shaw, G. B. C. (2008). Tourism by design: An analysis of architectural tourism and its influence on urban design from 1997 to 2007. University of California.

Soleimani, S., Bruwer, J., Gross, M. J., \& Lee, R. (2019). Astro-tourism conceptualisation as special-interest tourism (SIT) field: A phenomenological approach. Current Issues in Tourism, 22(18), 2299-2314. 
Zakariya, K., et.al. / Asian Journal of Environment-Behaviour Studies (ajE-Bs), 5(16) May / Aug 2020 (pp.59-74)

Switzerland Tourism. (2020). Factory and technical visits. Switzerland. https://www.myswitzerland.com/

Taman Tugu Project. (2020). Trees at Taman Tugu. Taman Tugu Project.

The Institution of Engineers Malaysia. (2019). GeoTechnical Engineering. IEM Official Website. https://www.mendeley.com/library/\#

Trauer, B. (2006). Conceptualising special interest tourism—frameworks for analysis. Tourism Management, 27(2), 183-200.

Tresidder, R., \& Deakin, E. L. (2019). Historic buildings and the creation of experiencescapes: looking to the past for future success. Journal of Tourism Futures, 5(2), 193-201.

UNWTO. (n.d.). Urban Tourism. World Tourism Organization: A United Nations Specialized Agency. Retrieved May 14, 2020, from https://www.unwto.org/urban-tourism

Valery. (2020). Architecture Walk, Kuala Lumpur (Self-Guided). GPSMYCITY.

Welch, A. (2020). Kuala Lumpur Architecture Tours. E-Architect. 